\title{
Micelle-Mediated Method for Simultaneous Determination of Ascorbic Acid and Uric Acid by Differential Pulse Voltammetry
}

\author{
Alaécio P. dos Reis, ${ }^{a}$ César R. T. Tarley ${ }^{b}$ and Lauro T. Kubota ${ }^{*, a}$ \\ ${ }^{a}$ Instituto de Química, Universidade Estadual de Campinas, CP 6154, 13084-971 Campinas-SP, Brazil \\ ${ }^{b}$ Departamento de Ciências Exatas, Universidade Federal de Alfenas, 37130-000 Alfenas-MG, Brazil
}

\begin{abstract}
O presente trabalho descreve uma metodologia analítica para determinação simultânea de ácido ascórbico (AA) e ácido úrico (AU) por voltametria de pulso diferencial empregando o surfactante catiônico cloreto de cetilpiridínio. Medidas voltamétricas de pulso diferencial realizadas em pH 7,0 revelaram que o meio micelar catiônico permite separar em $282 \mathrm{mV}$ os picos de oxidação de AA e AU na mesma solução, valor suficiente para determinar ambas as espécies simultaneamente. Como em pH 7,0 o AA está mais ionizado que o AU, sua atração eletrostática em direção às micelas catiônicas, formadas sobre a superfície do eletrodo de carbono vítreo, é maior; desta forma, promove a diminuição no sobrepotencial e o aumento na taxa de transferência de elétrons. Foram construídas curvas de calibração para AA e AU na faixa de concentração de 4,70 até $220 \mu$ mol L-1 e 0,50 até $110 \mu \mathrm{mol} \mathrm{L} \mathrm{L}^{-1}$. A metodologia proposta foi aplicada para a determinação de AA e AU em amostras de urina humana.
\end{abstract}

The present work describes an analytical methodology for simultaneous determination of ascorbic acid (AA) and uric acid (UA) by differential pulse voltammetry employing the cationic surfactant, cetylpyridinium chloride. Differential pulse voltammetry measurements revealed that the cationic micellar media may separate the oxidation peak potentials of AA and UA present in the same solution by about $282 \mathrm{mV}$, which is enough to determine both species simultaneously. As in $\mathrm{pH} 7.0$ the $\mathrm{AA}$ is more ionized than $\mathrm{UA}$, its electrostatic attraction towards the cationic micelles formed onto the surface of glassy carbon electrode is higher, therefore, promoting a decrease in the overpotential and increasing the electron transfer rate. Calibration curves to AA and UA in the concentration range from 4.70 up to $220 \mu \mathrm{mol} \mathrm{L} \mathrm{L}^{-1}$ and 0.50 up to $110 \mu \mathrm{mol} \mathrm{L}^{-1}$ were built. The proposed methodology was applied for the simultaneous determination of AA and UA in human urine samples.

Keywords: uric acid, ascorbic acid, differential pulse voltammetry, cationic surfactant, micelles

\section{Introduction}

Ascorbic acid (AA) and uric acid (UA) coexist in biological fluids such as blood and urine, ${ }^{1}$ being in practical medicine, necessary to determine AA and UA simultaneously. Ascorbic acid (a water soluble vitamin C) plays a vital role in processes of oxidation and reduction in the human organism by participating in many metabolic reactions. ${ }^{2} \mathrm{AA}$ has also been used to prevent and treat the common cold, mental illness, infertility and cancer. ${ }^{3}$ Moreover, ascorbic acid has also been used clinically in the treatment and prevention of

\footnotetext{
*e-mail: kubota@iqm.unicamp.br
}

scurvy. ${ }^{4}$ Uric acid (2,6,8-trihydroxypurine, UA) is the primary product of purine metabolism in the human body and is formed in liver and tissues during the oxidation of aminopurines. ${ }^{5}$ Its abnormal concentration level in urine and serum are symptoms of several diseases like gout, hyperuricaemia and Lesch-Nyhan syndrome. ${ }^{6,7}$ For instance, the concentration of uric acid in the blood of patients suffering from gout increases up to $1 \mathrm{mmol} \mathrm{L}^{-1}$, which is above the concentration of uric acid in blood for a healthy person. ${ }^{5,8}$ According to literature, ${ }^{8,9}$ the concentration of UA in serum is about $240-520 \mu \mathrm{mol} \mathrm{L}^{-1}$ and the urinary excretion is $1.49-4.46 \mathrm{mmol} \mathrm{L}^{-1}$ per $24 \mathrm{~h}$ for a healthy person. There are some methods, such as high-performance liquid chromatrography, ${ }^{10}$ ion-exchange 
chromatography ${ }^{11}$ and capillary electrophoresis ${ }^{12}$ for simultaneous determination of ascorbic acid and uric acid. However, these methods suffer from high implementation and operation cost; require sample pretreatment and in some cases are time consuming. In this way, the development of simple and rapid methods for the determination of AA and UA have attracted much attention and electrochemical procedures have been greatly employed to determine both based on their electrochemical activities. ${ }^{1,7,13}$ However, the direct electrooxidation of AA and UA at bare electrodes requires high overpotentials and $\mathrm{AA}$ and $\mathrm{UA}$ can be oxidized at a very close potential, which results in rather poor selectivity. The ability to determine AA and UA selectively has been a major goal of electroanalytical research. Since the basal concentration of AA and UA in biological samples varies from species to species in a wide range, from $10^{-7}$ to $10^{-3} \mathrm{~mol} \mathrm{~L}^{-1}$, both sensitivity and selectivity are of equal importance in developing voltammetric procedures. ${ }^{1,13}$

Various approaches have been attempted to solve these problems and a number of chemically modified electrodes have been developed to separate the electrochemical response of AA and UA. Among them a widely used method is to coat the electrode with an ion-exchange membrane such as Nafion film, which is mainly employed to determine UA in the presence of AA at acid medium. ${ }^{14,15}$ On the other hand, poly(3,4-dihydroxybenzaldehyde), ${ }^{16}$ polypyrroledodecyl sulfate, ${ }^{17} \beta$-cyclodextrin, ${ }^{6}$ carbon nanotube, ${ }^{13}$ selfassembly monolayer of thiol ${ }^{9}$ and clay modified electrodes ${ }^{18}$ were used to determine $\mathrm{UA}$ or AA in the presence of the other without an ion-exchange membrane.

Few works have given the deserved attention for the simultaneous determination of ascorbic acid and uric acid in biological fluids employing electrochemical techniques. Recently, a glassy carbon electrode modified with norepinephrine has been developed ${ }^{19}$ for simultaneous determination of AA and UA at $\mathrm{pH}$ 7.0. The authors reported that modified electrode shows electrocatalytic activity towards AA and UA and diminish the overpotential of both with respect at a bare electrode. Employing the differential pulse voltammetry they showed that the simultaneous determination of AA and UA with a welldistinguished two anodic peaks at potentials 180 and $290 \mathrm{mV}$, corresponding to the oxidation of AA and UA, respectively, could be possible. However, there is still an expanding demand for the development of a simple, reliable and efficient methodology for the simultaneous determination of AA and UA.

A novel method has seen described in the literature, which shows the oxidation of ascorbic acid and uric acid employing chemically modified glassy electrode (GC) with surfactant/clay films [cetyltrimethylammonium bromide (CTAB)/hydrotalcite-like] containing ferrocenecarboxylic acids. ${ }^{20}$ The authors showed that the surfactant molecules incorporated into the clay are promising towards oxidation of AA and UA. Recently, a glassy carbon electrode was modified with copper for simultaneous determination of ascorbic acid, uric acid and homovanillic acid. ${ }^{21}$ In spite of many chemically modified glassy electrodes have been developed, the use of micellar environment for simultaneous electrochemical determination at a bare electrode is still little exploited. The adsorption of surfactants onto surface electrode as well as the solubilization of electrochemically active compounds into micelle aggregates may mediate catalytic systems, allowing significant change in redox potential and charge transfer and diffusion coefficients of the electrode processes can be observed. ${ }^{22-24}$ Szymula and Narkiewicz-Michalez ${ }^{25}$ reported the behavior of electrochemical oxidation of ascorbic acid in aqueous solution with anionic and cationic surfactants, verifying significant changes in the oxidation peak potential as well as in the peak current value, mainly due to the surfactant film formed at the electrode/solution interface. According to authors, the negatively charged ascorbic acid has a tendency to accumulate in the positively charged crown of cationic micelles, which enhances the rate of oxidation and consequently provoking an increase in the peak current.

Simultaneous determination in micellar medium of the isomers catechol and hydroquinone in environmental samples has been recently demonstrated. ${ }^{26}$ The authors reported that the oxidation peak potentials of catechol and hydroquinone were separated by $100 \mathrm{mV}$ in the presence of cetypyridinium bromide (CPB) at $\mathrm{pH}$ 6.8. The exploration of micellar environment in the electrochemical behaviors of AA and UA and their simultaneous determination has not been reported in the literature at the best our knowledge.

Thus, the present work describes a study based on cyclic voltammetry and differential pulse voltammetry techniques, for simultaneous determination of AA and UA in cationic CPC micellar system (cetylpyridinium chloride), using a glassy carbon electrode as a working electrode. The presence of cationic micelles promotes the separation of voltammetric peaks of AA and UA, which facilitates the simultaneous determination of both. The method was applied in the simultaneous determination of AA and UA in urine samples by differential pulse voltammetry.

\section{Experimental}

All electrochemical experiments were performed using a potentiostat/galvanostat Autolab® PGSTAT-12 (Eco Chemie B.V.; The Netherlands). Experiments were 
performed in a conventional single-compartment threeelectrode cell. A glassy carbon electrode (Metrohm, $2.0 \mathrm{~mm}$ in diameter) employed as a working electrode was carefully polished with $0.5 \mu \mathrm{m}$ alumina slurry on a flat surface, rinsed thoroughly with deionized water, and then sonicated immediately before using in deionized water for $2 \mathrm{~min}$. A Platinum wire was employed as an auxiliary electrode. All potentials were recorded in relation to a saturated calomel reference electrode (SCE).

All reagents such as uric acid (UA, Merck), ascorbic acid (AA, J. T. Baker) and CPC (cetylpyridinium chloride, SigmaAldrich), were used as received without further purification. Aqueous solutions were prepared with deionized water ( $\rho>18.2 \mathrm{M} \Omega \mathrm{cm}$, Millipore Milli-Q system) and other chemicals used were of analytical grade. For voltammetric experiments, unless otherwise indicated, a $0.1 \mathrm{~mol} \mathrm{~L}^{-1}$ aqueous phosphate buffer $(\mathrm{pH}=7.0)$ solution was used as supporting electrolyte. The potential for voltammetric experiments was recorded from $-200 \mathrm{mV}$ to $+600 \mathrm{mV}$.

\section{Results and Discussion}

\section{Electrochemical oxidation of $A A$ and $U A$}

Figure 1 shows the cyclic voltammograms $(\mathrm{CVs})$ obtained at a glassy carbon electrode for the oxidation of ascorbic acid (AA) and uric acid (UA) in the absence and presence of cationic surfactant $\mathrm{CPC}$ at a scan rate of $50 \mathrm{mV} \mathrm{s}^{-1}$ in $0.1 \mathrm{~mol} \mathrm{~L}^{-1}$ phosphate buffer solution ( $\mathrm{pH} 7.0$ ). As can be observed, the anodic peak potential $\left(\mathrm{E}_{\mathrm{pa}}\right)$ for AA appears at $190 \mathrm{mV}$ in absence of cationic surfactant CPC and the electron transfer rate seems to be sluggish due to fouling of the electrode surface by the adsorption of the oxidation product of AA (Figure 1A, dashed line). In the presence of surfactant (Figure 1A, solid line), the anodic peak potential of AA appears at $-10 \mathrm{mV}$, a difference of $200 \mathrm{mV}$ when compared to the electrochemical measurements in absence of CPC. The anodic peak was shifted towards more negative values probably due to interaction between the negatively charged $\mathrm{AA}$ at $\mathrm{pH} 7.0$ and the cationic surfactant. It is also important to stress out that, beyond the anodic peak of AA in the presence of CPC shift towards more negative values, the peak currents (Ipa) increased, being an indicative that the rate of electron transfer was increased. The explanation of these behaviors can be assigned to the adsorption of the CPC micelles onto electrode surface forming a positively charged hydrophilic film oriented towards the water bulk phase, which may decrease the overpotential of the electrode and increase the electron transfer rate, as already previously demonstrated. ${ }^{27}$ The cyclic voltamogram obtained for UA in the absence (dashed
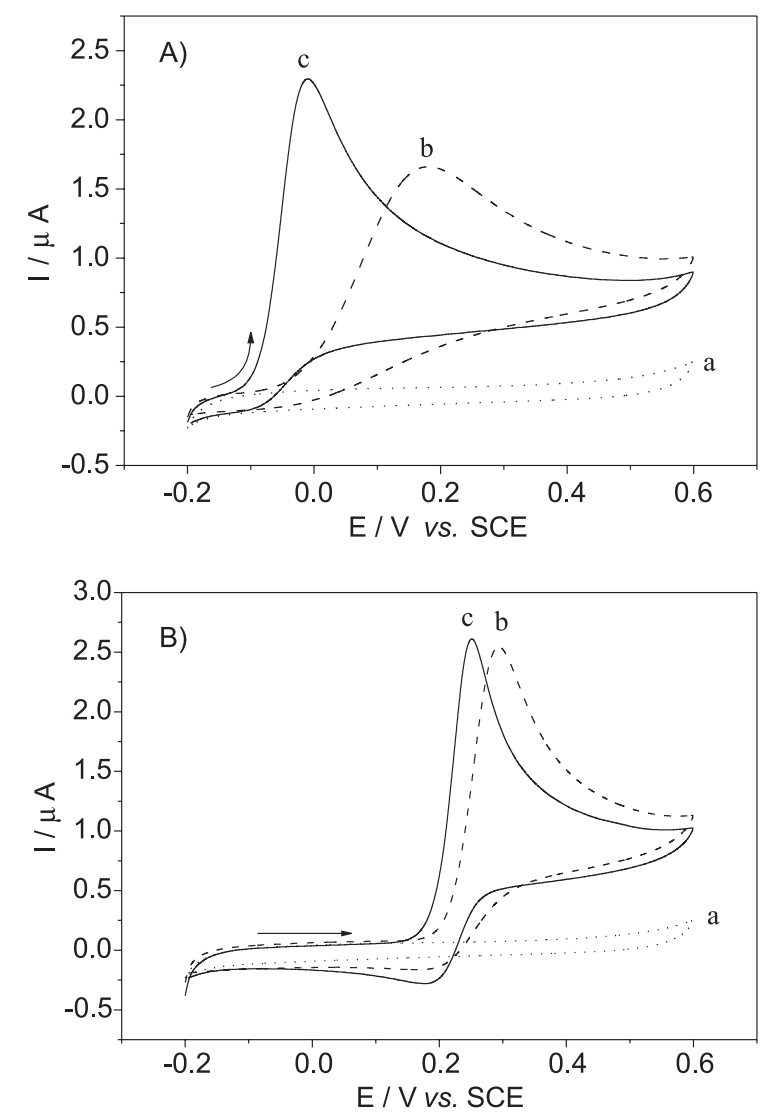

Figure 1. Cyclic voltammograms for oxidation of $100 \mu \mathrm{mol} \mathrm{L}^{-1}$ ascorbic acid (AA) (A) and $100 \mu \mathrm{mol} \mathrm{L}^{-1}$ uric acid (UA) (B) recorded at a glassy carbon electrode in a $0.1 \mathrm{~mol} \mathrm{~L}^{-1}$ phosphate buffer solution $(\mathrm{pH} 7.0)$. Curve a (dotted line): in $1.0 \mathrm{mmol} \mathrm{L}^{-1}$ cetylpyridinium chloride (CPC) and in the absence of AA or UA; curve b (dashed line): AA or UA in the absence of CPC; curve $\mathrm{c}$ (solid line): AA or UA in the presence of CPC. $\mathrm{v}=50 \mathrm{mV} \mathrm{s}^{-1}$.

line) and in presence (solid line) of surfactant is shown in Figure 1B. As verified, in the presence of surfactant both anodic and cathodic peak currents present a slight increase, while anodic peak potential was shifted towards more negative values ( 293 to $249 \mathrm{mV}$ ). These results, similarly verified for AA, demonstrate that the UA redox process was promoted in aqueous CPC solution. A briefly comparison of electrochemical behavior of AA e UA in the presence of $\mathrm{CPC}$, shows that the shifting of $E_{\mathrm{pa}}$ towards more negative values is more pronounced for AA. It probably occurs because the experiments were performed at $\mathrm{pH} 7.0$, which the acid ascorbic molecule is negatively charged (first $\mathrm{pKa}=4.17$ ), while the ionization rate of uric acid at $\mathrm{pH} 7.0$, is lower than ascorbic acid since its $\mathrm{pKa}$ is around 5.4.28 In order to verify whether the electrode process is controlled by adsorption a linear sweep voltammetry was performed. The $\mathrm{I}_{p a}$ followed a linear relationship with the square roots of scan rate $\left(\mathrm{I}_{p a} v s . v^{1 / 2}\right)$ from 25 up to $150 \mathrm{mV} \mathrm{s}^{-1}$ for both species. This result indicated that the charge transfer is a diffusion controlled process. 


\section{Simultaneous detection of $A A$ and $U A$ by $C V$}

As commented, the use of CPC surfactant provides the shifting of anodic peak potential towards more negative values for AA and UA. However, in the absence of CPC surfactant the anodic peak potentials for both AA and UA are very much closed, where their simultaneous determination can be difficult owing to their overlapped signal. As displayed in Figure 2 (dashed line), the cyclic voltammograms for the mixture of AA and UA in the absence of CPC surfactant shows the anodic peak for UA overlapped with the anodic peak of AA. On the other hand, in the presence of CPC surfactant the anodic peaks for AA and UA were well separated by $300 \mathrm{mV}$ (Figure 2, solid line), being of paramount importance for simultaneous determination of these species and, of course, for the development of analytical method.

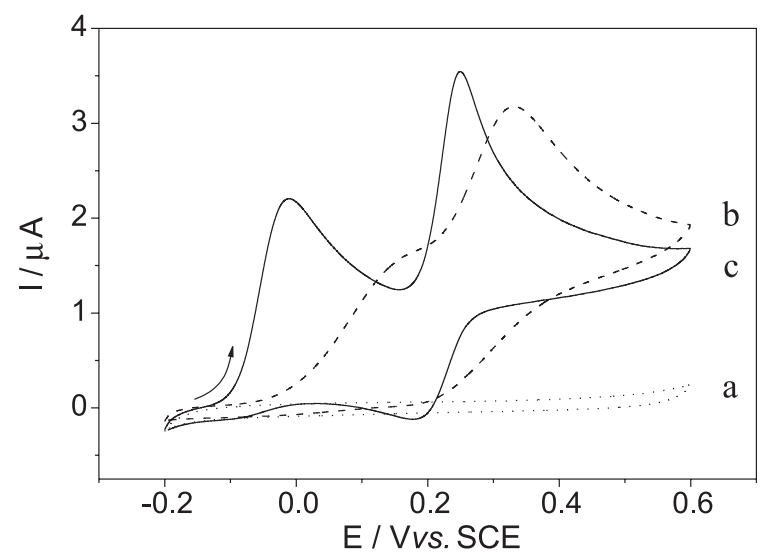

Figure 2. Cyclic voltammograms of mixtures of $100 \mu \mathrm{mol} \mathrm{L} \mathrm{L}^{-1} \mathrm{AA}$ and $100 \mu \mathrm{mol} \mathrm{L}-1$ UA recorded at a glassy carbon electrode in a $0.1 \mathrm{~mol} \mathrm{~L}^{-1}$ phosphate buffer solution ( $\mathrm{pH} 7.0$ ). Curve a (dotted line): in $1.0 \mathrm{mmol} \mathrm{L}^{-1}$ cetylpyridinium chloride (CPC) and in the absence of both AA and UA; curve $\mathrm{b}$ (dashed line): AA + UA in the absence of CPC; curve c (solid line): $\mathrm{AA}+\mathrm{UA}$ in the presence of CPC. $\mathrm{v}=50 \mathrm{mV} \mathrm{s}^{-1}$.

\section{Simultaneous determination of $A A$ and $U A$ by DPV}

In order to simultaneously determine AA and UA aiming an analytical application for real samples, mainly in biological fluids, the separation of AA and UA anodic peaks were carried out by DPV. Figure 3 (inset figure) shows that the oxidation peak for AA is seriously overlapped by oxidation peak of UA in the absence of CPC surfactant. However, in the presence of CPC surfactant two well-defined oxidation peaks were observed. The remarkable separation of AA and UA peaks was achieved by shifting of both AA and UA oxidation peaks toward more negative values, $-49 \mathrm{mV}$ and $233 \mathrm{mV}$, respectively. Similarly to the behavior of AA and UA oxidation by

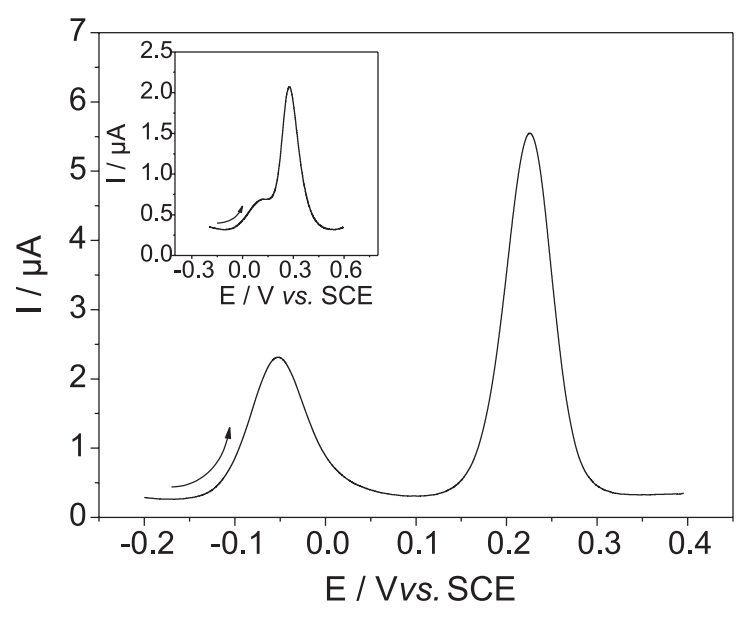

Figure 3. Differential pulse voltammograms (DPV) for the mixture of a solution of $100 \mu \mathrm{mol} \mathrm{L} \mathrm{L}^{-1} \mathrm{AA}$ and $100 \mu \mathrm{mol} \mathrm{L}-1$ UA in $0.1 \mathrm{~mol} \mathrm{~L}^{-1}$ phosphate buffer ( $\mathrm{pH} 7.0$ ) and in micelle media (1.0 mmol $\left.\mathrm{L}^{-1} \mathrm{CPC}\right)$. Insert graphic shows the response for oxidation of AA and UA in the absence of CPC, both coexisting in solution. Potential amplitude was $50 \mathrm{mV}$. Step potential of $5 \mathrm{mV}$.

$\mathrm{CV}$, in DPV the separation of AA and UA peaks was of $282 \mathrm{mV}$, thus allowing us determine simultaneously these species.

The influence of different AA and UA concentration on separation effectiveness of oxidation peaks were also evaluated. Figure 4A, shows the DPV of UA using

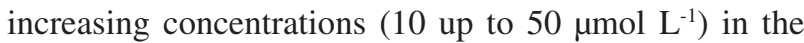
presence of AA fixed at $100 \mu \mathrm{mol} \mathrm{L}{ }^{-1}$. As verified, the separation of oxidation peaks as well as the relationship between UA concentration and peak current was not affected by presence of AA. Figure 4B, in a similar way, also shows that peak currents of AA are proportional to

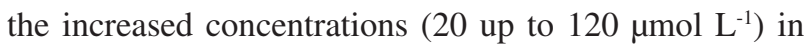
the presence of $20 \mu \mathrm{mol} \mathrm{L}-1 \mathrm{UA}$. According to these results achieved, it is possible to note that the micellar environment based on use of CPC surfactant is an outstanding medium for separation of AA and UA oxidation peaks even at different concentrations.

In spite of good performance of micellar environment for separation AA and UA anodic peaks at different concentrations, differential pulse voltammograms were recorded by increasing both AA and UA concentrations. As one can see in Figure 5, there still is a good separation of anodic peaks as well as a proportional relationship between peak current and concentration.

\section{Effect of $p H$ on the oxidation of $A A$ and $U A$}

The effect of $\mathrm{pH}$ on the peak current and peak potential of the catalytic oxidation of UA and AA were investigated. Results are shown in Figure 6. As can be seen, the peak 

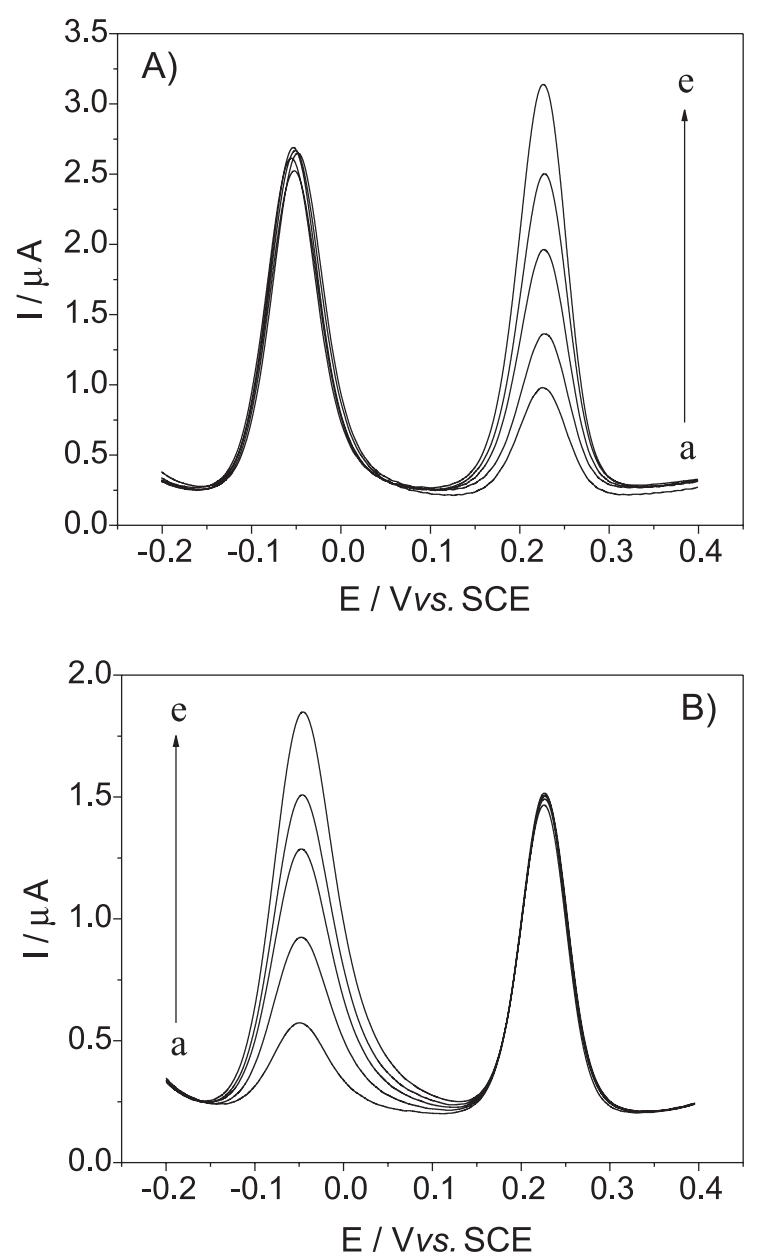

Figure 4. Differential pulse voltammograms (DPV) for the mixture of AA and UA in $0.1 \mathrm{~mol} \mathrm{~L}^{-1}$ phosphate buffer ( $\mathrm{pH}$ 7.0) and in micelle media (1.0 mmol L-1 CPC). (A) The concentration of AA was fixed and the concentration of UA was varied (i.e. [AA] $=100 \mu \mathrm{mol} \mathrm{L}^{-1}$; [UA]: (a) 10, (b) 20, (c) 30, (d) 40, (e) $50 \mu \mathrm{mol} \mathrm{L}^{-1}$ ). (B) The concentration of AA was varied and the concentration of UA was fixed (i.e. [UA] $=20 \mu \mathrm{mol} \mathrm{L}^{-1}$; [AA]: (a) 20, (b) 40, (c) 60, (d) 80, (e) 100, (f) $120 \mu \mathrm{mol} \mathrm{L}^{-1}$ ).

potential for UA oxidation shows a linear variation with $\mathrm{pH}$ and is shifted towards more negative potentials with a slope of about $-53 \mathrm{mV} \mathrm{pH}^{-1}$, which suggests that the total number of electrons and protons that participates in the charge transfer was the same. As the oxidation of uric acid is known to occur by a two-electron transfer, thus the number of protons involved is also predicted to be two. Figure 6 also shows the trend of peak potential of AA with $\mathrm{pH}$ values. As can be seen, the slope of the $\mathrm{E}_{\mathrm{p}} v s . \mathrm{pH}$ is about $-34 \mathrm{mV} \mathrm{pH}^{-1}$ between $\mathrm{pH} 5.0-8.0$, indicating that a $2 \mathrm{e}^{-} / 1 \mathrm{H}^{+}$reaction was involved in the oxidation process. Consequently, the overall electrode reaction can be classified as an electrochemical reaction followed by a chemical reaction process as previously reported. ${ }^{1,13}$ From Figure 7, it can be seen the variation of peak current of UA and AA at a GCE with $\mathrm{pH}$ in the presence of $1.0 \mathrm{mmol} \mathrm{L}^{-1}$ of CPC. As shown in this Figure, the peak current of UA increase slightly from $\mathrm{pH}$ 5.0 to 7.0

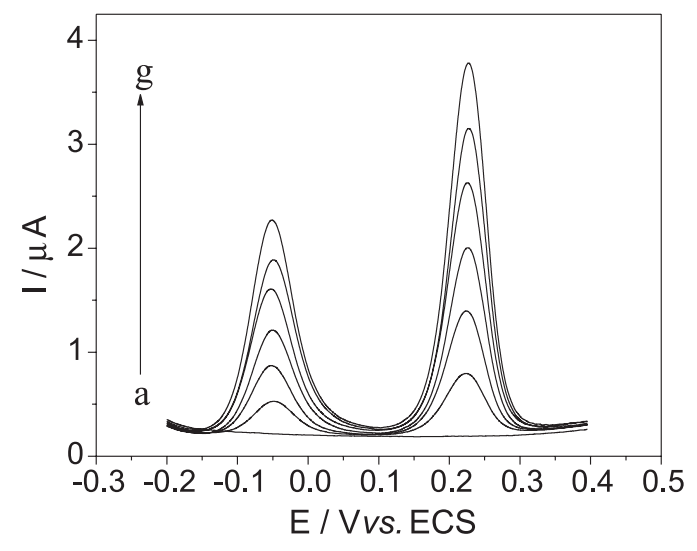

Figure 5. Differential pulse voltammograms (DPV) for the mixture of AA and UA in $0.1 \mathrm{~mol} \mathrm{~L}^{-1}$ phosphate buffer $(\mathrm{pH} 7.0)$ and in micelle media (1.0 mmol L $\left.{ }^{-1} \mathrm{CPC}\right)$. Concentrations of both AA and UA are simultaneously changed: (a) [AA] and [UA] 0; (b) [AA] 20 and [UA] 10; (c) [AA] 40 and [UA] 20; (d) [AA] 60 and [UA] 30; (e) [AA] 80 and [UA] 40; (f) [AA] 100 and [UA] 50; (g) [AA] 120 and [UA] $60 \mu \mathrm{mol} \mathrm{L}^{-1}$.

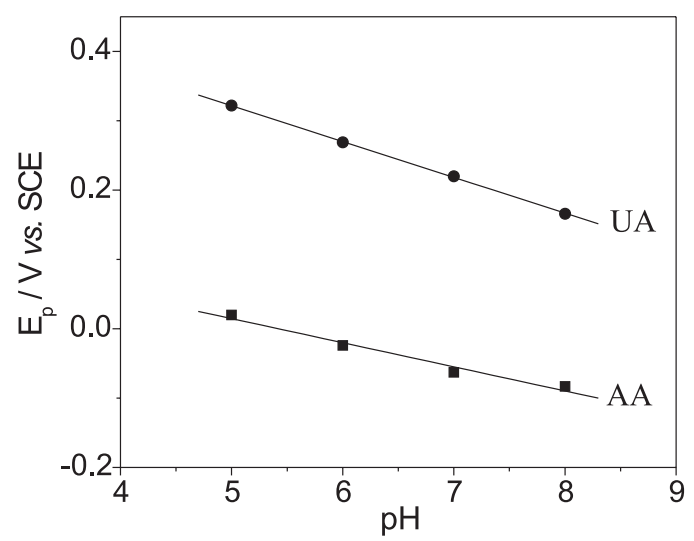

Figure 6. Dependence on $\mathrm{pH}$ of the peak potentials $\left(\mathrm{E}_{\mathrm{p}}\right)$ for $100 \mu \mathrm{mol} \mathrm{L} \mathrm{L}^{-1}$ $\mathrm{AA}$ and $100 \mu \mathrm{mol} \mathrm{L}-1 \mathrm{UA}$ in the presence of $1.0 \mathrm{mmol} \mathrm{L}^{-1} \mathrm{CPC}$.

and then decrease with increasing $\mathrm{pH}$, while for the ascorbic acid a maximum value at about $\mathrm{pH} 7.0$ is reached. Therefore, taking into account the physiological $\mathrm{pH}$ (7.4) and sensitivity of the method, the bulk solution $\mathrm{pH}$ was selected as 7.0. All experiments were carried out by fixing the concentration of CPC surfactant at $1.0 \mathrm{mmol} \mathrm{L}^{-1}$ according to previous work. ${ }^{27}$ This value provides an enough concentration for covering the electrode surface by CPC surfactant, and consequently, the saturation of the adsorbed surfactant cannot affect the electrode oxidation process anymore, thus resulting in slight variation of $\mathrm{E}_{\mathrm{pa}}$ and $\mathrm{I}_{\mathrm{pa}}$.

Analytical features and application of the method for simultaneous AA and UA determination in human urine samples

After the good performance of CPC surfactant for separation of AA and UA oxidation peaks in different 


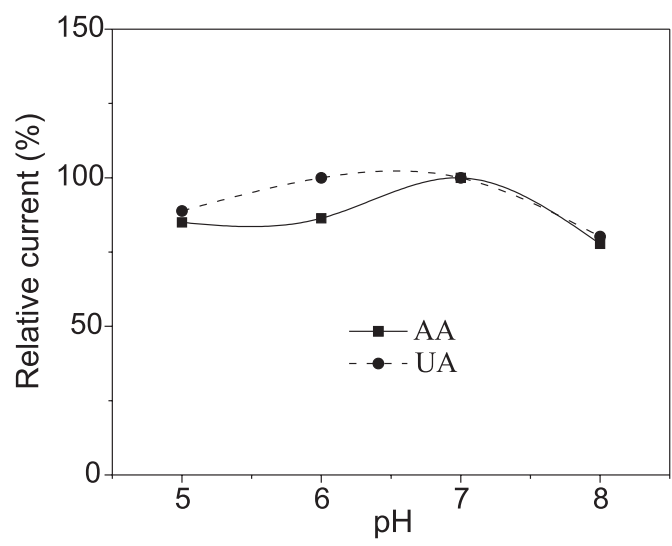

Figure 7. Dependence on $\mathrm{pH}$ of the peak currents $\left(\mathrm{I}_{\mathrm{p}}\right)$ for $100 \mu \mathrm{mol} \mathrm{L} \mathrm{L}^{-1}$ AA and $100 \mu \mathrm{mol} \mathrm{L}^{-1} \mathrm{UA}$ in the presence of $1.0 \mathrm{mmol} \mathrm{L}^{-1} \mathrm{CPC}$. Currents data was showed as a relative response.

proportions of these species, the calibration curves were constructed and according to results obtained from linear range, AA can be determined in the 4.71 up to $220 \mu \mathrm{mol} \mathrm{L}^{-1}$ range and UA from 0.50 up to $110 \mu \mathrm{mol} \mathrm{L}^{-1}$. The fitting regression equations for these data were $\mathrm{I}_{\mathrm{pa}} / \mu \mathrm{A}=0.265( \pm 0.005)+0.025( \pm 0.006)[\mathrm{AA}]$ with a correlation coefficient of $(\mathrm{r}=0.9989)$ and $\mathrm{I}_{\mathrm{pa}} / \mu \mathrm{A}=$ $0.265( \pm 0.005)+0.063( \pm 0.004)[\mathrm{UA}]$ with a correlation coefficient of $(r=0.9998)$ for AA and UA species, respectively. The limits of detection (LOD) and quantification (LOQ) calculated according to IUPAC, ${ }^{29}$ were found to be 1.47 and $4.71 \mu \mathrm{mol} \mathrm{L}^{-1}$ for AA and 0.13 and $0.48 \mu \mathrm{mol} \mathrm{L}^{-1}$ for UA. These values of LOD and LOQ are similar to those obtained from previous work. . $^{30,31}$

In order to assess the feasibility of the analytical system, the developed method was applied for AA and UA determination in urine samples. For this task, an aliquot of $250 \mu \mathrm{L}$ of urine samples collected from the laboratory without any treatment was added into the electrochemical cell containing $1.0 \mathrm{mmol} \mathrm{L}^{-1}$ of CPC and the volume was made up to $5 \mathrm{~mL}$ with $0.1 \mathrm{~mol} \mathrm{~L}^{-1}$ phosphate buffer at $\mathrm{pH}$ 7.0. According to Figure 8, the differential pulse voltammograms were recorded from -200 to $400 \mathrm{mV}$, for the diluted urine. It was verified an oxidation peak at

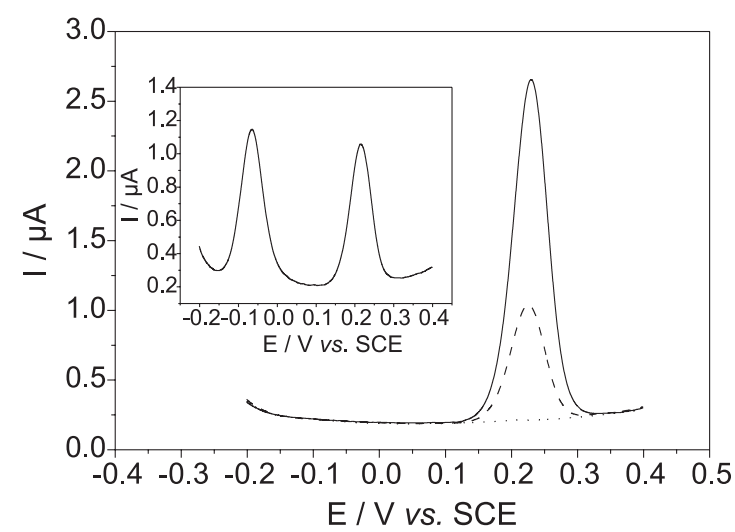

Figure 8. Differential pulse voltammograms (DPV) recorded for uric acid (UA) at a glassy carbon electrode in a $0.1 \mathrm{~mol} \mathrm{~L}^{-1}$ phosphate buffer solution $(\mathrm{pH} 7.0)$ and in micelle media $\left(1.0 \mathrm{mmol} \mathrm{L}^{-1} \mathrm{CPC}\right)$. (Dotted line) in the presence of CPC and absence of UA, (dashed line) addition of urine sample, (solid line) addition of a standard solution of $40 \mu \mathrm{mol} \mathrm{L}{ }^{-1} \mathrm{UA}$. Insert graphic shows the response for addition of a standard solution of $30 \mu \mathrm{mol} \mathrm{L}^{-1} \mathrm{AA}$ and urine sample. Dilution factor of urine samples: 20 times.

$228 \mathrm{mV}$ (dashed solid) corresponding to the UA peak in the presence of CPC surfactant, while no peak was observed for AA. Addition of a standard solution of $40 \mu \mathrm{mol} \mathrm{L}^{-1} \mathrm{UA}$ increased substantially the peak current, thus confirming the presence of UA in the urine samples. The feasibility of proposed method for UA and AA determination in biological fluids, such as urine samples, was attested by addition of $10 \mu \mathrm{L}$ of a standard solution of $15 \mathrm{mmol} \mathrm{L}^{-1} \mathrm{AA}$ into the electrochemical cell containing diluted urine sample $\left(250 \mu \mathrm{L}\right.$ in $5 \mathrm{~mL}$ of electrochemical cell) in $1.0 \mathrm{mmol} \mathrm{L}^{-1}$ of $\mathrm{CPC}$ and $0.1 \mathrm{~mol} \mathrm{~L}^{-1}$ phosphate buffer at $\mathrm{pH}$ 7.0. The validation of the method was checked by adding known amounts of AA and UA in the urine samples. As showed in Table 1, good recoveries ranging from 96.0 to $107.3 \%$ confirm the accuracy of the method and the suitability and reliability of the micelle electrochemical measurements for determination of AA and UA mixture in biological fluids. The content obtained of UA in the urine is in agreement with previous work published. ${ }^{32}$

Table 1. Results from simultaneous determination of AA and UA in urine samples by proposed method ${ }^{\text {a }}$

\begin{tabular}{|c|c|c|c|c|c|c|}
\hline \multicolumn{2}{|c|}{ Urine Samples } & \multirow{2}{*}{$\frac{\text { Detected } /(\mu \mathrm{mol} \mathrm{L}-1)}{49.0 \pm 0.5}$} & \multirow{2}{*}{$\frac{\text { Spike } /\left(\mu \mathrm{mol} \mathrm{L}^{-1}\right)}{50.0}$} & \multirow{2}{*}{$\begin{array}{c}\text { After spike / }\left(\mu \mathrm{mol} \mathrm{L}^{-1}\right) \\
99.8 \pm 0.7\end{array}$} & \multirow{2}{*}{$\begin{array}{c}\text { Recovery / (\%) } \\
100.8 \pm 0.7\end{array}$} & \multirow{2}{*}{$\frac{\text { Total value }^{\mathrm{b}} /\left(\mathrm{mg} \mathrm{L}^{-1}\right)}{164.7 \pm 1.7}$} \\
\hline Sample 1 & UA & & & & & \\
\hline & AA & ND & 30.0 & $28.8 \pm 0.1$ & $96.0 \pm 0.3$ & - \\
\hline \multirow[t]{2}{*}{ Sample 2} & UA & $46.5 \pm 0.6$ & 50.0 & $96.9 \pm 0.1$ & $100.4 \pm 0.1$ & $156.3 \pm 2.0$ \\
\hline & AA & ND & 30.0 & $28.9 \pm 0.1$ & $96.6 \pm 0.3$ & - \\
\hline \multirow[t]{2}{*}{ Sample 3} & UA & $47.8 \pm 0.4$ & 50.0 & $97.7 \pm 0.5$ & $99.9 \pm 0.5$ & $160.7 \pm 1.3$ \\
\hline & AA & ND & 30.0 & $32.2 \pm 0.2$ & $107.3 \pm 0.7$ & - \\
\hline
\end{tabular}

$\mathrm{ND}=$ not detected; ${ }^{\mathrm{a} T h e}$ results are average of five determinations; ${ }^{\mathrm{b}}$ Total value was obtained by multiplying the detected value and the dilution factor 20 . 


\section{Conclusions}

In this current paper were shown the electrochemical behavior making possible the separation of UA and AA oxidation peaks using differential pulse voltammetry in the presence of cationic surfactant (cetylpyridinium chloride). The oxidation peaks of both species shift towards more negative values owing to adsorption of positively charged CPC onto the electrode surface. The charged hydrophilic film of CPC promotes the decrease of overpotential of the electrode for the UA and AA oxidation. As the $\mathrm{pH}$ employed in this study was 7, AA is negatively charged $(\mathrm{pKa}=4.17)$ while $\mathrm{UA}(\mathrm{pKa}=5.4)$ is less dissociated. Therefore, electrostatic attraction between AA and CPC adsorbed onto electrode surface makes possible the shifting of AA oxidation peaks towards much more negative values than that verified to UA and, consequently, allowed the simultaneous determination of UA and AA. From the practical point of view, the developed analytical method using DPV showed its feasibility and suitability from its application in complex samples for simultaneous UA and AA determination. Moreover, it could be shown that the method is characterized by good stability owing to anti-fouling properties of CPC avoiding the fouling of the electrode surface by adsorption of the oxidation product and, mainly, by simplicity and rapidity whether one considers those methods based on chemically modified electrode, which commonly use tedious procedures.

\section{Acknowledgments}

The authors thank the CNPq, FAPEMIG, FAPESP and CAPES for financial support and fellowships.

\section{References}

1. Zhang, L.; Lin, X.; Analyst 2001, 126, 367.

2. Liu, A; Anzai, J.; Anal. Bioanal. Chem. 2004, 380, 98.

3. Shankaran, D. R.; Iimura, K.; Kato, T.; Sens. Actuators, B 2003, $94,73$.

4. Teixeira, M. F. S.; Ramos, L. A.; Ramos, Fatibello-Filho, O.; Cavalheiro, E. T. G.; Anal. Bioanal. Chem. 2003, 376, 214.

5. Abdullin, I. F.; Bakanina, Y. N.; Turova, E. N.; Budnikov, G. K.; J. Anal. Chem. 2001, 56, 453.

6. Zheng, L.; Wu, S.; Lin, X.; Nie, L.; Rui, L.; Electroanalysis 2001, 13, 1351.

7. John, S. A.; J. Electroanal. Chem. 2005, 579, 249.
8. Roy, P. R.; Okajima, T.; Ohsaka, T.; J. Electroanal. Chem. 2004, 561,75 .

9. Raj, C. R.; Ohsaka, T.; J. Electroanal. Chem. 2003, 540, 69.

10. Iriyama, K.; Yoshiura, M.; Iwamoto, T.; Ozaki, Y.; Anal. Biochem. 1984, 141, 238.

11. Etoh, T.; Iwatake, M.; Miyazaki, M.; Harada, K.; Nakayama, M.; Sugii, A.; Uji, Y.; Okabe, H.; J. Liq. Chromatogr. 1992, 15, 1565.

12. Yao, X.; Wang, Y.; Chen, G.; J. Biomed. Chromatogr. 2007, 21 , 526.

13. Ye, J. S,; Wen, Y.; Zhang, W. D.; Gan, L. M.; Xu, G. Q.; Shen, F. S.; Electroanalysis 2003, 15, 1693.

14. Zen, J. M.; Hsu, C. T.; Talanta 1998, 46, 1363.

15. Zen, J. M.; Tang, J. S.; Anal. Chem. 1995, 67, 1892.

16. Gao, Z.; Siow, K. S.; Ng, A.; Zhang, Y.; Anal. Chim. Acta 1997, $343,49$.

17. Gao, Z.; Chen, B.; Zi, M.; J. Electroanal. Chem. 1994, 365, 197.

18. Zen, J. M.; Chen, P. J.; Anal. Chem. 1997, 69, 5087.

19. Zare, H. R.; Memarzadeh, F.; Ardakani, M. M.; Namazian, M.; Golabi, S. M.; Electrochim. Acta 2005, 50, 3495.

20. Fernández, L.; Carrero, H.; Electrochim. Acta 2005, 50, 1233.

21. Selvaraju, T.; Ramaraj, R.; Electrochim. Acta 2007, 52, 2998.

22. Rusling, J. F.; Acc. Chem. Res. 1991, 24, 75.

23. Sivagnanam, U.; Palaniandavar, M.; Electroanal. Chem. 1996, 410, 43.

24. Yi, H.; Wu, K.; Hu, S.; Cui, D.; Talanta 2001, 55, 1205.

25. Szymula, M.; Narkiewicz-Michalek, J.; Colloid Polym. Sci. 2002, 281, 1142.

26. Juan, P.; Zuo-Ning, G.; Anal. Bioanal. Chem. 2006, 384, 1525.

27. dos Reis, A. P.; Tarley, C. R. T.; Kubota, L. T.; Talanta 2005, 67,829

28. Jen, J.; Jou, J.; Ilagovan, G.; Analyst 1998, 123, 1345.

29. Long, G. L.; Winefordner, J. D.; Anal. Chem. 1983, 55, 712.

30. Jin, G. P.; Lin, X. Q.; Gong, J. M.; J. Electroanal. Chem. 2004, $569,135$.

31. Domenech, A.; Garcia, H.; Domenech-Carbo, M. T.; Galletero, M. S.; Anal. Chem. 2002, 74, 562.

32. Kalimuthu, P.; Suresh, D.; John, S. A.; Anal. Biochem. 2006, 357,188

Received: November 27, 2007 Web Release Date: October 2, 2008

FAPESP helped in meeting the publication costs of this article. 